\title{
Impact of HONO sources on the performance of mesoscale air quality models
}

\author{
M. Gonçalves ${ }^{\mathrm{a}, \mathrm{b}, *}$, D. Dabdub ${ }^{\mathrm{c}}$, W.L. Chang ${ }^{\mathrm{c}}$, O. Jorba ${ }^{\mathrm{b}}$, J.M. Baldasano ${ }^{\mathrm{a}, \mathrm{b}}$ \\ ${ }^{a}$ Environmental Modeling Laboratory, Projects Department, Technical University of Catalonia, Barcelona, Spain \\ ${ }^{\mathrm{b}}$ Earth Sciences Department, Barcelona Supercomputing Center, Barcelona, Spain \\ ${ }^{\mathrm{c}}$ Department of Mechanical and Aerospace Engineering, University of California, Irvine, Irvine, California, USA
}

\section{A R T I C L E I N F O}

\section{Article history:}

Received 18 November 2011

Received in revised form

8 February 2012

Accepted 24 February 2012

\section{Keywords:}

Tropospheric chemistry

Hydroxyl radical

Nitrous acid sources

Secondary pollutants formation

Air quality modeling

\begin{abstract}
A B S T R A C T
Nitrous acid (HONO) photolysis constitutes a primary source of $\mathrm{OH}$ in the early morning, which leads to changes in model gas-phase and particulate matter concentrations. However, state-of-the-art models of chemical mechanisms share a common representation of gas-phase chemistry leading to HONO that fails in reproducing the observed profiles. Hence, there is a growing interest in improving the definition of additional HONO sources within air quality models, i.e. direct emissions or heterogeneous reactions. In order to test their feasibility under atmospheric conditions, the WRF-ARW/HERMES/CMAQ modeling system is applied with high horizontal resolution $\left(4 \times 4 \mathrm{~km}^{2}\right)$ to Spain for November $24-27,2008$. HONO modeled sources include: (1) direct emissions from on-road transport; $\mathrm{NO}_{2}$ hydrolysis on aerosol and ground surfaces, the latter with (2) kinetics depending exclusively on available surfaces for reaction and (3) refined kinetics considering also relative humidity dependence; and (4) photoenhanced $\mathrm{NO}_{2}$ reduction on ground surfaces. The DOMINO measurement campaign performed in El Arenosillo (Southern Spain) provides valuable HONO observations. Modeled HONO results are consistently below observations, even when the most effective scenario is assessed, corresponding to contributions of direct emissions and $\mathrm{NO}_{2}$ hydrolysis with the simplest kinetics parameterization. With the additional sources of HONO, $\mathrm{PM}_{2.5}$ predictions can be up to $14 \%$ larger in urban areas. Quantified impacts on secondary pollutants have to be taken as a low threshold, due to the proven underestimation of HONO levels. It is fundamental to improve HONO sources definition within air quality models, both for the scientific community and decision makers.
\end{abstract}

(c) 2012 Elsevier Ltd. All rights reserved.

\section{Introduction}

Nitrous acid (HONO) photolysis is recognized as an important source of hydroxyl radical, OH (Platt et al., 1980; Elshorbany et al., 2009), being responsible for up to $34 \%-60 \%$ of morning $\mathrm{OH}$ production in urban areas (Alicke et al., 2003; Elshorbany et al., 2009; Ren et al., 2003). OH being a primary daytime oxidant in the troposphere, HONO sources and sinks have to be adequately represented within air quality models in order to accurately predict air pollution levels.

Homogeneous gas-phase chemistry (Platt et al., 1980) alone fails to capture the observed HONO profiles (Calvert et al., 1994; Winer and Biermann, 1994; Kurtenbach et al., 2001). Thus, other direct and indirect sources of HONO must be accounted for to bridge the gap between modeling studies and ambient measurements. A

\footnotetext{
* Corresponding author. Environmental Modeling Laboratory, Projects Department, Technical University of Catalonia, Barcelona, Spain.

E-mail address: maria.goncalves@upc.edu (M. Gonçalves).
}

primary source of HONO is combustion processes, which was widely recognized in the early nineties (Calvert et al., 1994; Winer and Biermann, 1994). On-road transport makes the largest contribution to direct HONO emissions, especially in urban areas. Heterogeneous chemistry is another potential key HONO source in the atmosphere, but the specifics of chemical mechanisms and reaction kinetics still remain unclear.

One proposed pathway for HONO formation in the atmosphere is the hydrolysis of $\mathrm{NO}_{2}$ on wet surfaces (Kleffmann et al., 1998; Kurtenbach et al., 2001; Finlayson-Pitts et al., 2003; Stutz et al., 2004):

$2 \mathrm{NO}_{2}+\mathrm{H}_{2} \mathrm{O} \rightarrow \mathrm{HONO}+\mathrm{HNO}_{3}$.

The reduction of $\mathrm{NO}_{2}$ adsorbed on surfaces could also lead to nitrous acid production. Soot and other aerosol surfaces have been suggested as effective substrates for reaction (Ammann et al., 1998), which could be enhanced due to sunlight (Stemmler et al., 2007; Monge et al., 2010). However, the small surface area of aerosols when compared to ground surfaces and the rapid surface deactivation processes, raise the question of the relative contribution of 
reactions on particles to the atmospheric HONO budget (Sarwar et al., 2008). Modeling studies estimated the contribution of reactions on soot surfaces to HONO daily levels being lower than $2 \%$ (Li et al., 2010), even in highly polluted urban areas such as Mexico City. In contrast, An et al. (2011) and Li et al. (2011) estimate on average that $59 \%$ of HONO is produced via reactions on aerosols for the Beijing, Tianjin and Hebei province of China, which could be due primarily to the high concentrations of $\mathrm{PM}_{10}$ (up to $300 \mu \mathrm{g} \mathrm{m}^{-3}$ ) and $\mathrm{PM}_{2.5}$ (up to $200 \mu \mathrm{g} \mathrm{m}^{-3}$ ). Chamber experiments using humic acid films (Stemmler et al., 2006) suggest that ground surfaces that can act as possible substrates for photoenhanced $\mathrm{NO}_{2}$ reduction.

Heterogeneous conversion of nitric acid $\left(\mathrm{HNO}_{3}\right)$ on primary organic aerosols (Ziemba et al., 2010) or ground surfaces (RiveraFigueroa et al., 2003) yields HONO, however those reactions have been recently discredited under atmospheric conditions (Kleffmann et al., 2004; Kleffmann and Wiesen, 2005). Other works (e.g. Zhou et al., 2003), proposed that the photolysis of $\mathrm{HNO}_{3}$ on ground and aerosol surfaces could be a potential HONO source. A modeling study over the eastern United States region showed contributions to HONO diurnal levels from that source up to $32 \%$ (Sarwar et al., 2008). However, such high contribution is not supported by chamber experiments (Rohrer et al., 2005).

Other photoenhanced HONO production pathways are the photolysis of ortho-nitrophenols (Bejan et al., 2006), or photoelectronically excited $\mathrm{NO}_{2}\left(\mathrm{NO}_{2}^{*}\right)$ reaction with water (Li et al., 2008, 2009). Both reactions yield significant HONO production below specific conditions, unlikely to be frequent in the atmosphere, such as relatively high concentrations of nitro-phenols (on the order of ppmv) or particular solar density fluxes (Li et al., 2010; Carr et al., 2009). Modeling studies considering $\mathrm{NO}_{2}^{*}$ reaction with water (Wennberg and Dabdub, 2008) have concluded that further investigation is needed in order to include it within atmospheric models.

A recently conducted field campaign in Southern Spain (Sörgel et al., 2011), DOMINO, identified a strong diurnal source of HONO. Sörgel and coworkers showed that known photoenhanced HONO sources, such as $\mathrm{NO}_{2}$ reduction on aerosols and $\mathrm{NO}_{2}^{*}$ reaction with water, contribute up to $10 \%$ to HONO observed levels, concluding that there must be an additional unidentified diurnal HONO source. Su et al. (2011) suggest that this unknown diurnal source can be due an acid-base equilibrium between aqueous phase of soil nitrite, originated from biological nitrification and denitrification processes, and gas-phase nitrous acid, depending on the $\mathrm{pH}$ and the nitrite concentration of soil. Further studies of HONO release from soil and related processes of biogeochemical nitrogen cycling are recommended by the authors.

The main goal of this work is to assess the ability of current state-of-the-art air quality models to reproduce HONO profiles by including the latest findings in laboratory and field studies on HONO emissions and chemical production pathways. Here, the WRF-ARW/HERMES/CMAQ modeling system, which is the basis of the CALIOPE system (Baldasano et al., 2008a; Baldasano et al., 2011; Pay et al., 2010, 2012), is used to test the contribution of different sources to HONO levels in Spain during November 24-27, 2008. Model predictions are compared to HONO observations from the DOMINO campaign performed in El Arenosillo station (Southern Spain) for the analyzed period (Sörgel et al., 2011). Previous modeling studies have included heterogeneous HONO production on ground surfaces as simple parameterizations considering constant surface to volume ratios (Vogel et al., 2003; Li et al., 2010), or neglecting the relative humidity influence on kinetics (Sarwar et al., 2008). Here, those variables influencing HONO heterogeneous production are characterized in detail and their effects analyzed. For the first time, the HONO impact on $\mathrm{OH}$ release in urban areas of Spain is quantified and its effect on secondary pollutants production examined.

\section{Methods}

The modeling domain is Spain (d02 in Fig. 1) with $4 \times 4 \mathrm{~km}$ horizontal resolution and 15 sigma vertical layers up to the top of the atmosphere, set at $50 \mathrm{hPa}$. The selected period for the study covers November, 24-27, 2008. The Advanced Research Weather Research and Forecasting (WRF-ARW) Model v3.0.1.1 (Michalakes et al., 2004; Skamarock and Klemp, 2008) provides the necessary meteorological inputs for the air quality simulations. The High Elective Resolution Modeling System (HERMES; Baldasano et al., 2008b) is used to estimate emissions of gas-phase and aerosol pollutants. Previous studies showed that $\mathrm{NO}_{2}$ levels in Spain are consistently underestimated (Baldasano et al., 2008b; Baldasano et al., 2011), so $\mathrm{NO}_{x}$ emissions enhancement by a factor of 2 is chosen for this study after some preliminary examinations. The third generation Models-3
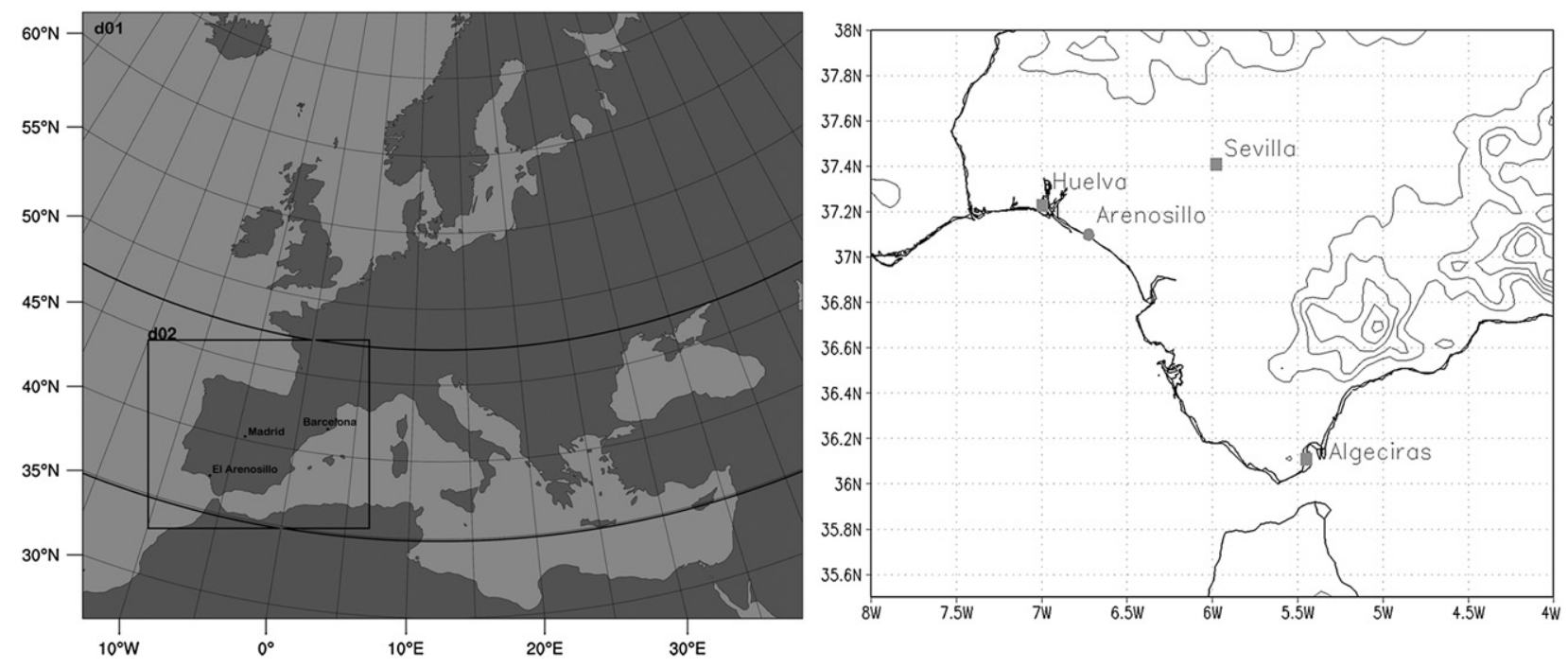

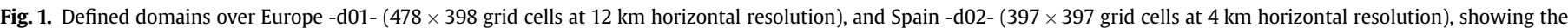

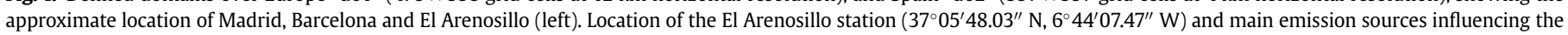
area, namely Sevilla urban area, Huelva urban and industrial area and Algeciras harbor and industrial area (right). 
Community Mesoscale Air Quality (CMAQ) Modeling System v4.7.1 (Foley et al., 2010) provides the evolution of the air quality levels. In particular, gas phase chemistry is represented by the Carbon Bond 5 (CB05) chemical mechanism (Yarwood et al., 2005). Aerosols chemistry and processes are treated through the AERO5 module (Binkowski and Roselle, 2003; Byun and Schere, 2006; Carlton et al., 2010). Integrated Reaction Rate module (IRR, Gipson, 1999) is applied here to assess the contribution of different $\mathrm{OH}$ sources to total $\mathrm{OH}$ release in the troposphere.

Initial conditions are provided by means of a 24 hour spin-up. Boundary conditions are obtained from a coarser simulation covering the European region $(478 \times 398$ grid cells, $12 \mathrm{~km} \times 12 \mathrm{~km}$ horizontal resolution, 15 vertical sigma layers, d01 in Fig. 1), performed with the CALIOPE modeling system. Emissions for the European domain come from the EMEP database (www.emep.int) and are disaggregated to the $12 \mathrm{~km}$ grid. CALIOPE (www.bsc.es/ caliope) has been used extensively to assess the air quality levels in Spain, both in the hindcast and forecast modes (e.g. Baldasano et al., 2008a; Pay et al., 2010, 2012).

\subsection{HONO emissions}

Studies using different vehicles and engine tests have shown that HONO to $\mathrm{NO}_{x}$ emission ratios range from $0.01 \%$ to $1.8 \%$ (Kurtenbach et al., 2001), depending on the vehicle and fuel type, and the oxygen content. Generally, diesel vehicles under rich operation conditions lead to higher $\mathrm{HONO} / \mathrm{NO}_{x}$ ratios than gasoline-fuelled vehicles under lean operation conditions (Kurtenbach et al., 2001). Kirschtetter et al. (1996) measured a $\mathrm{HONO} / \mathrm{NO}_{x}$ ratio of $0.29 \%$ $( \pm 0.05 \%)$ in a tunnel study conducted in California, where more than $99 \%$ of the vehicle fleet were gasoline-fuelled vehicles. Kurtenbach et al. (2001) sampled a $0.8 \%( \pm 1.0 \%)$ ratio in Germany, where the average vehicle fleet composition included around $75 \%$ of gasoline fuelled cars. The latter results have already been adopted by several modeling communities, such as the Models-3 Community from US-EPA and the CHIMERE community in France (Sarwar et al., 2008; INERIS, 2009). Therefore, a $0.8 \% \mathrm{HONO} / \mathrm{NO}_{x}$ ratio is applied in this study to emissions from on-road transport. This conservative approach may slightly underestimate HONO emissions, as in Spain vehicle fleet composition accounts for higher ratios of diesel-fuelled vehicles (51\% in 2008; DGT, 2010) than those reported by Kurtenbach et al. (2001) for Germany (around 25\%).

\subsection{HONO production via heterogeneous chemistry and photolytic pathways}

$\mathrm{NO}_{2}$ hydrolysis on the ground, buildings and vegetation surfaces (R1) is believed to be a major contributor to HONO formation in the atmosphere, especially at night (Finlayson-Pitts et al., 2003; Vogel et al., 2003). Kinetics of reaction (R1) is shown to be first order in $\mathrm{NO}_{2}$ (Kleffmann et al., 1998; Finlayson-Pitts et al., 2003) and a function of relative humidity (Stutz et al., 2004). While previous modeling studies have considered R1 on ground surfaces (Sarwar et al., 2008), the role of relative humidity has not been tested. This work evaluates the impact of two different kinetic parameterizations for the $\mathrm{NO}_{2}$ hydrolysis on surfaces. First, the existing approach included in the CMAQv4.7.1 model is applied (Sarwar et al., 2008). It uses a kinetic constant, $k_{1}$ in $\left[\mathrm{s}^{-1}\right]$, based on Kurtenbach et al. (2001),

$k_{1}=5.0 \times 10^{-5}\left(\frac{S}{V}\right)$,

where $S\left(\mathrm{~m}^{2}\right)$ represents the available surface area within a given volume, $V\left(\mathrm{~m}^{3}\right)$. Ground surfaces, namely vegetation and building surfaces, are parameterized following Sarwar et al. (2008). Aerosol surfaces are computed within the AERO5 module in CMAQv4.7.1.
Second, a new expression is derived using the HONO production rate reported by Finlayson-Pitts et al. (2003) for R1, $7 \times 10^{-7}[(\mathrm{ppm}$ $\mathrm{HONO}$ ) (ppm NO$)^{-1} \mathrm{~s}^{-1}$ ]. This reaction is pseudo-first order in $\mathrm{NO}_{2}$. The kinetic constant is known to be dependent on the surface area to volume ratio available for the reaction and the relative humidity $(\mathrm{RH})$, where the relationship is approximately linear between $10 \%$ and 90\% RH (Finlayson-Pitts et al., 2003). Taking into account the chamber conditions at the $\mathrm{RH}$ of $50 \%$ and the $S / V$ ratio of $3.4 \mathrm{~m}^{-1}$, as reported by Finlayson-Pitts et al. (2003), the expression for the kinetic constant, $k_{2}\left[\mathrm{~s}^{-1}\right]$, can be written as

$k_{2}=4.05 \times 10^{-9} \cdot \mathrm{RH}\left(\frac{S}{V}\right)$,

with $\mathrm{RH}$ in \% and $S / V$ in $\mathrm{m}^{-1}$.

There are evidences from field campaigns of a strong diurnal HONO source, which recent laboratory studies suggest to be first order in $\mathrm{NO}_{2}$ and occurring at surfaces (Stemmler et al., 2006). Therefore,

$\mathrm{NO}_{2} \stackrel{h v}{\rightarrow}$ HONO.

Kinetics is parameterized following the recommendations from Li et al. (2010) and Aumont et al. (2003), therefore the first order constant for the reaction (R2) is estimated via

$k_{3}=\frac{1}{8} \cdot v_{\mathrm{NO}_{2}} \cdot\left(\frac{S}{V}\right) \cdot \gamma_{\mathrm{NO}_{2}}$

where $v_{\mathrm{NO}_{2}}$ is the deposition velocity of $\mathrm{NO}_{2}\left(\mathrm{~m} \mathrm{~s}^{-1}\right), S / V$ is the surface to volume ratio $\left(\mathrm{m}^{-1}\right)$ and $\gamma_{\mathrm{NO}_{2}}$ is the uptake coefficient for $\mathrm{NO}_{2}$, which is higher during daytime than nighttime in order to represent the photoenhanced HONO formation. More specifically, $\gamma_{\mathrm{NO}_{2}}$ is set to be $1 \times 10^{-6}$ for nighttime (Kurtenbach et al., 2001), $2 \times 10^{-5}$ for light density lower than $400 \mathrm{~W} \mathrm{~m}^{-2}$, and a linearly scaled function for higher light density values, eq. (4), (Li et al., 2010),

$\gamma_{\mathrm{NO}_{2}}=2 \times 10^{-5} \cdot\left(\frac{\text { light density }}{400}\right)$

\subsection{Summary of scenarios}

In order to assess the influence of traffic HONO emissions, heterogeneous hydrolysis of $\mathrm{NO}_{2}$ on surfaces and photoenhanced $\mathrm{NO}_{2}$ reduction on surfaces, five scenarios are developed and examined in this study (Table 1). All scenarios use CB05 (Yarwood et al., 2005) for the gas phase chemistry representation, which constitutes the only source of HONO in the BASE scenario. The EM08 scenario includes exclusively HONO emissions, as $0.8 \%$ of $\mathrm{NO}_{x}$ emitted from on-road traffic, and gas phase chemistry. Besides direct emissions, $\mathrm{NO} 2 \mathrm{H}$ adds $\mathrm{NO}_{2}$ hydrolysis on ground and aerosol surfaces with kinetics defined by Eq. (1), which is the default CMAQv4.7.1 configuration. Similar to $\mathrm{NO} 2 \mathrm{H}, \mathrm{NO} 2 \mathrm{HRH}$ also includes $\mathrm{NO}_{2}$ hydrolysis on surfaces, but the kinetics is redefined by Eq. (2) to consider the influence of relative humidity. Finally, PHOT considers direct HONO emissions and both hydrolysis and photoenhanced reduction of $\mathrm{NO}_{2}$ on surfaces according to Eqs. (3) and (4).

\section{Results and discussion}

\subsection{Model evaluation}

Modeling results are assessed against air quality measurements in Spain for November 24-27, 2008. Hourly concentration of $\mathrm{O}_{3}$, 
Table 1

Summary of defined scenarios.

\begin{tabular}{|c|c|c|c|c|}
\hline \multirow[t]{2}{*}{ Case } & \multirow[t]{2}{*}{ Identifier } & \multirow[t]{2}{*}{ HONO emissions } & \multicolumn{2}{|c|}{$\begin{array}{l}\mathrm{NO}_{2} \text { heterogeneous production on } \\
\text { various surfaces }\end{array}$} \\
\hline & & & Aerosols & Ground \\
\hline 1 & BASE & None & No & No \\
\hline 2 & EM08 & $\begin{array}{l}0.8 \% \text { of } \mathrm{NO}_{x} \text { from } \\
\text { mobile sources }\end{array}$ & No & No \\
\hline 3 & $\mathrm{NO} 2 \mathrm{H}$ & $\begin{array}{l}0.8 \% \text { of } \mathrm{NO}_{x} \text { from } \\
\text { mobile sources }\end{array}$ & Yes & $\begin{array}{l}\text { Yes, } k_{1} \text { derived from } \\
\text { Eq. (1) for R1 }\end{array}$ \\
\hline 4 & $\mathrm{NO} 2 \mathrm{HRH}$ & $\begin{array}{l}0.8 \% \text { of } \mathrm{NO}_{x} \text { from } \\
\text { mobile sources }\end{array}$ & Yes & $\begin{array}{l}\text { Yes, } k_{2} \text { derived from } \\
\text { Eq. (2) for } \mathrm{R} 1\end{array}$ \\
\hline 5 & PHOT & $\begin{array}{l}0.8 \% \text { of } \mathrm{NO}_{x} \text { from } \\
\text { mobile sources }\end{array}$ & Yes & $\begin{array}{l}\text { Yes, } k_{3} \text { derived from Eqs. ( } 3 \text { ) } \\
\text { and ( } 4 \text { ) for R1 and R2 }\end{array}$ \\
\hline
\end{tabular}

$\mathrm{NO}_{2}$ and $\mathrm{SO}_{2}$ is obtained from 9 rural background stations from the European Monitoring and Evaluation Program (EMEP, www.emep. int). $\mathrm{PM}_{2.5}$ hourly concentrations for 2 air quality stations in Spain and $\mathrm{PM}_{10} 24$-h means from 27 stations are provided by the "Centro Superior de Investigaciones Científicas" (CSIC). Comparison of the BASE case against measurements (Table 2) shows slight underpredictions for $\mathrm{NO}_{2}$ (Mean Fractional Bias -MFB- of -9.8\%) and substantial underestimation of $\mathrm{PM}_{2.5}$ hourly concentrations (Mean Normalized Bias Error -MNBE- of $-42.2 \%)$. On the other hand, $\mathrm{O}_{3}$ concentrations predicted by the model are higher than observations (MFB of 36.7\%). High model to observation correlation for $\mathrm{NO}_{2}$ (Fig. 2) indicates that $\mathrm{NO}_{2}$ dynamics are generally well captured by the model.

\subsection{Assessment of different HONO sources}

Predicted HONO levels by WRF-ARW/HERMES/CMAQ are compared to observations from the DOMINO campaign in El Arenosillo air quality station (Sörgel et al., 2011). The station is located in a forested area mainly composed of pine trees that can be affected by industrial plumes from a refinery and a power plant located $20 \mathrm{~km}$ away in the northwest direction, depending on the meteorological conditions. Plumes arriving from the harbor and industrial area of Algeciras can also affect this station (Fig. 1).

HONO observed levels in El Arenosillo follow diurnal dynamics, characterized by a build-up during the late afternoon and nighttime, with maximum concentrations below $250 \mathrm{ppt}$, followed by a drop in concentration during morning due to photolysis (sun rises around 7:00 UTC, 8:00 local time, as Spain is UTC +1 in wintertime). Peaks above 100 ppt at 8:00 UTC, November 25 and 26, are attributed mainly to transported plumes downward from the Sevilla area, coinciding with $\mathrm{NO}_{2}$ peaks above $10 \mu \mathrm{g} \mathrm{m}^{-3}$ (Fig. 3).

Gas-phase chemistry alone (BASE case) yields HONO levels in El Arenosillo below 20 ppt (Fig. 3). HONO predicted concentrations are underestimated (MNBE of -94.06\%) and show an anticorrelation with observed values $(r=-0.33)$, because peaks are

Table 2

Statistical parameters for the BASE case when comparing WRF-ARW/HERMES/ CMAQ hourly model predictions of $\mathrm{NO}_{2}, \mathrm{SO}_{2}$ and $\mathrm{O}_{3}$ face to observations from rural background air quality stations from the EMEP network. Hourly $\mathrm{PM}_{2.5}$ and $24-\mathrm{h}$ average $\mathrm{PM}_{10}$ predicted concentrations are compared to observations from the CSIC network in Spain during the November 24-27, 2008.

\begin{tabular}{lrrrrc}
\hline & $\mathrm{NO}_{2}$ & \multicolumn{1}{c}{$\mathrm{SO}_{2}$} & $\mathrm{O}_{3}$ & $\mathrm{PM}_{2.5}$ & $\begin{array}{l}\mathrm{PM}_{10} \\
(24 \text {-h ave.) }\end{array}$ \\
\hline MOD (average conc.) $\mu \mathrm{g} \mathrm{m}^{-3}$ & 3.5 & 1.0 & 81.6 & 6.3 & 4.1 \\
OBS (average conc.) $\mu \mathrm{g} \mathrm{m}^{-3}$ & 3.9 & 0.8 & 57.4 & 11.6 & 9.9 \\
Mean bias ( $\mu \mathrm{g} \mathrm{m}^{-3}$ ) & -0.4 & 0.1 & 24.2 & -5.3 & -5.8 \\
MNBE (\%) & 11.2 & 30.8 & 51.9 & -42.2 & -56.2 \\
MFB (\%) & -9.8 & -41.2 & 36.7 & -80.5 & -89.5 \\
\hline
\end{tabular}

predicted around midday. Such false peak of HONO caused by gasphase chemistry alone has been discussed previously (Sarwar et al., 2008).

WRF-ARW/HERMES/CMAQ reproduces the HONO diurnal dynamics properly in the $\mathrm{NO} 2 \mathrm{H}$ case (with a correlation between observed and modeled concentrations of 0.55) - Fig. 3. In particular, morning peaks of HONO on November 25 and 26 are captured by the model. On the contrary, situations dominated by westerlies, such as 0:00 UTC to 7:00 UTC on November 24, correspond to a clear underestimation of HONO levels (Figs. 3 and 4). In these cases, dominant winds favor the transport of plumes from the industrial area of Huelva, characterized by high $\mathrm{NO}_{2}$ levels. The underestimation suggests the lack of additional HONO sources, which could be attributed to emission sources besides traffic and chemical mechanisms other than $\mathrm{NO}_{2}$ hydrolysis on surfaces. In spite of that fact, the $\mathrm{NO} 2 \mathrm{H}$ scenario is the most effective in producing HONO in the El Arenosillo region, where direct HONO emissions from traffic do not have a noticeable influence. In fact, EM08 scenario underestimates the HONO levels by an order of magnitude. HONO dynamics in this case are not captured either, with a correlation factor between model and observations of 0.11 , indicating that chemistry plays an important role in HONO formation in areas with limited on-road traffic emissions. The emissions of other activity sectors, such as industrial combustion processes should be explored in order to assess their potential contribution as HONO sources.

$\mathrm{NO} 2 \mathrm{HRH}$, the scenario with relative humidity dependent parameterization, yields negligible HONO in the El Arenosillo area. Examining the whole Spanish domain, only a few ppt of HONO are produced for $\mathrm{NO}_{2}$ concentrations above $90 \mu \mathrm{g} \mathrm{m}^{-3}$ over the largest urban areas with high traffic emissions. Therefore, kinetics as parameterized in Eq. (2) is not effective in producing HONO under atmospheric conditions. Even at locations with the highest relative humidity $(\mathrm{RH}=100 \%)$, the reaction rate from Eq. (2) would still be two orders of magnitude lower than the rate from Eq. (1). Evidence of the influence of $\mathrm{RH}$ on HONO production has been proved by means of field campaigns (Stutz et al., 2004), thus our results suggest that additional measurement campaigns and chamber experiments are needed in order to better parameterize $\mathrm{RH}$ dependence within kinetics in air quality models.

The PHOT case is comparable to the approach by Li et al. (2010) for photolytic HONO formation pathways. Based on our model results, HONO production as parameterized by Eqs. (3) and (4) is relatively negligible, even at the highest $\mathrm{NO}_{2}$ concentrations in main urban areas. Efficient photolytic production found by previous studies, such as $17 \%$ of $\mathrm{HONO}$ production via $\mathrm{NO}_{2}$ hydrolysis and photoenhanced $\mathrm{NO}_{2}$ reduction on surfaces for Mexico City (Li et al., 2010), is mainly caused by location specific features and governing parameter assumptions. First, Mexico City is a densely populated and highly polluted area, where $\mathrm{NO}_{2}$ peaks range from $96 \mu \mathrm{g} \mathrm{m}^{-3}$ to $188 \mu \mathrm{g} \mathrm{m}^{-3}$ (Li et al., 2010), significantly higher than those predicted in Spanish urban areas. For instance, in Madrid, maximum $\mathrm{NO}_{2}$ concentrations of $125 \mu \mathrm{g} \mathrm{m}^{-3}$ are predicted for November 25 at 9:00 UTC. Morning peaks on November 24, 26 and 27 are always below $100 \mu \mathrm{g} \mathrm{m}^{-3}$. In addition, a land-use dependent approach is considered in this study for the parameterization of the surfaces available for reaction (Sarwar et al., 2008), with $S / V$ as a function of the percentage of urban area and the leaf area index. $\mathrm{Li}$ et al. (2010) assumed the bulk surface of the model as a reactive surface (with a constant $S / V$ ratio of $0.1 \mathrm{~m}^{-1}$ ), which could be a valid approach for a densely populated area such as Mexico City, but it is not applicable to other regions such as Spain. In addition, the strength of the photolytic source depends on the deposition velocity of $\mathrm{NO}_{2}$, which peaks during daytime at $0.6-0.7 \mathrm{~cm} \mathrm{~s}^{-1}$. The enhancement due to solar radiation is at the most a factor of 1.2 , as solar radiation hitting the ground ranges from 0 to roughly 

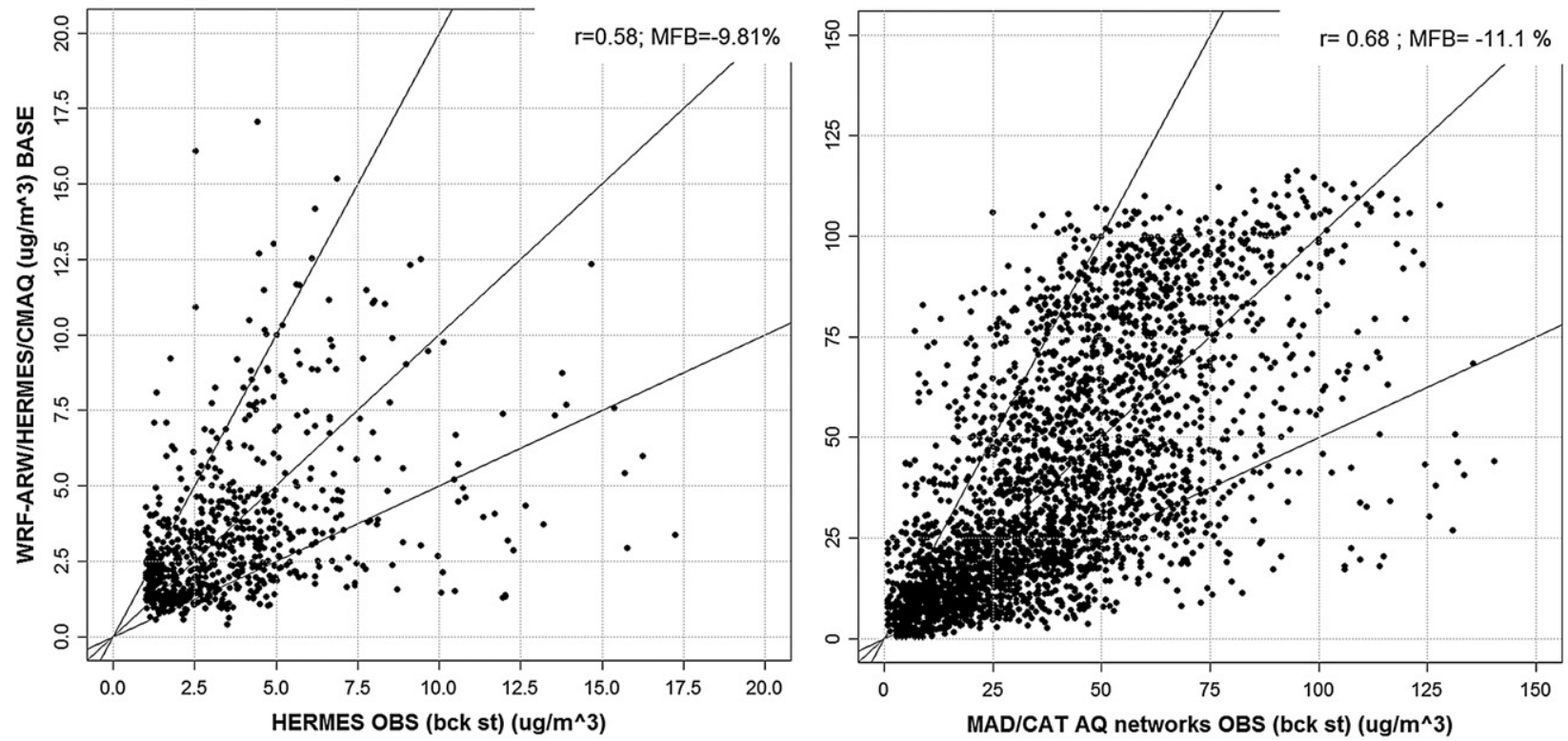

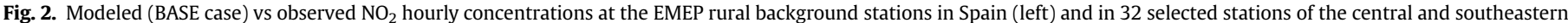
Spain representative of different environments: urban, suburban, rural; and emissions influence: background, traffic and industrial stations (right).

$600 \mathrm{~W} \mathrm{~m}^{-2}$. Therefore, when compared to Eq. (1), Eqs. (3) and (4) yield HONO production rates three orders of magnitude lower, even when all parameters are set to their maximum values. It should be noted that this analysis corresponds to a wintertime episode and that during summertime enhancement on kinetics due to solar radiation would be higher. Even so, it is unlikely that the current parameterization would yield a reaction rate three orders of magnitude larger during the summer. These results show that the parameterization of factors affecting the kinetics, such as the $S / V$ ratio, has to be handled carefully, as it has an important impact on final predictions and it is subject to high uncertainty.

From now on, the discussion will be centered in the $\mathrm{NO} 2 \mathrm{H}$ case, which includes $\mathrm{HONO}$ emissions as $0.8 \%$ of $\mathrm{NO}_{x}$ emissions from traffic and heterogeneous $\mathrm{NO}_{2}$ hydrolysis on ground and aerosol surfaces, with kinetics derived from Eq. (1). In those rural areas affected by $\mathrm{NO}_{x}$ plumes (both from large urban areas or industrial sites), HONO peaks can reach 200-300 ppt. However, HONO levels predicted in remote rural areas are usually below $50 \mathrm{ppt}$ (Fig. 5).

Urban regions are expected to present higher HONO levels, primarily associated to on-road traffic emissions, but also produced via heterogeneous chemistry on available surfaces such as buildings. There are no references of urban measurements of HONO in Spain, but previous studies worldwide are analyzed as a reference (e.g. Platt et al., 1980; Wentzell et al., 2010). Urban HONO levels exhibit wide variations depending on the location particularities, such as emissions and meteorological conditions. Nevertheless, observations follow a trend showing maximum HONO values before sunrise from $0.4 \mathrm{ppb}$ to $15 \mathrm{ppb}$. Daytime concentrations of HONO are low, falling sometimes below the detection limits.
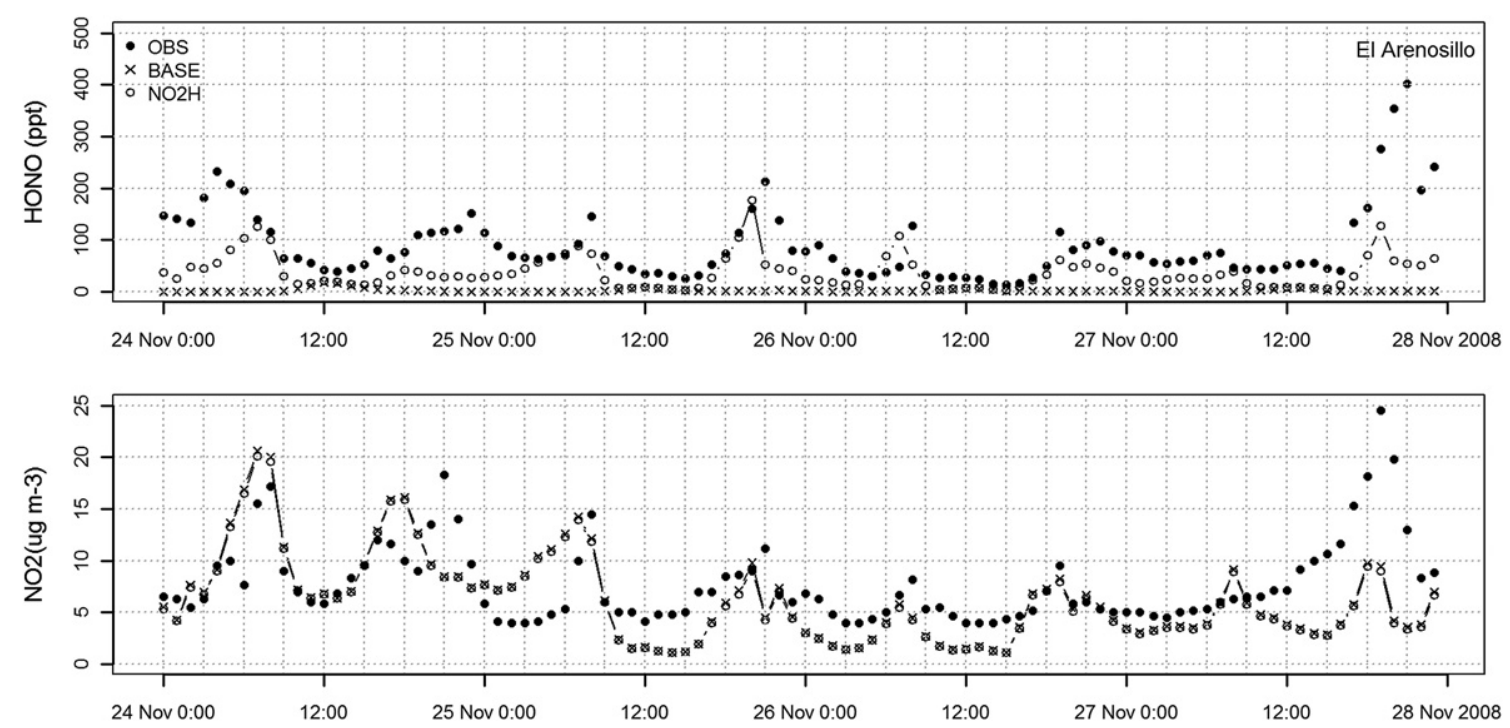

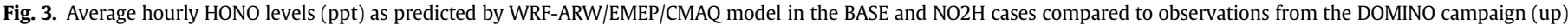

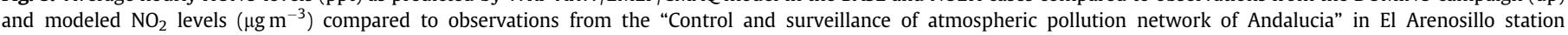
$\left(37^{\circ} 05^{\prime} 48.03^{\prime \prime} \mathrm{N}, 6^{\circ} 44^{\prime} 07.47^{\prime \prime} \mathrm{W}\right)$ for November $24-27,2008$. 

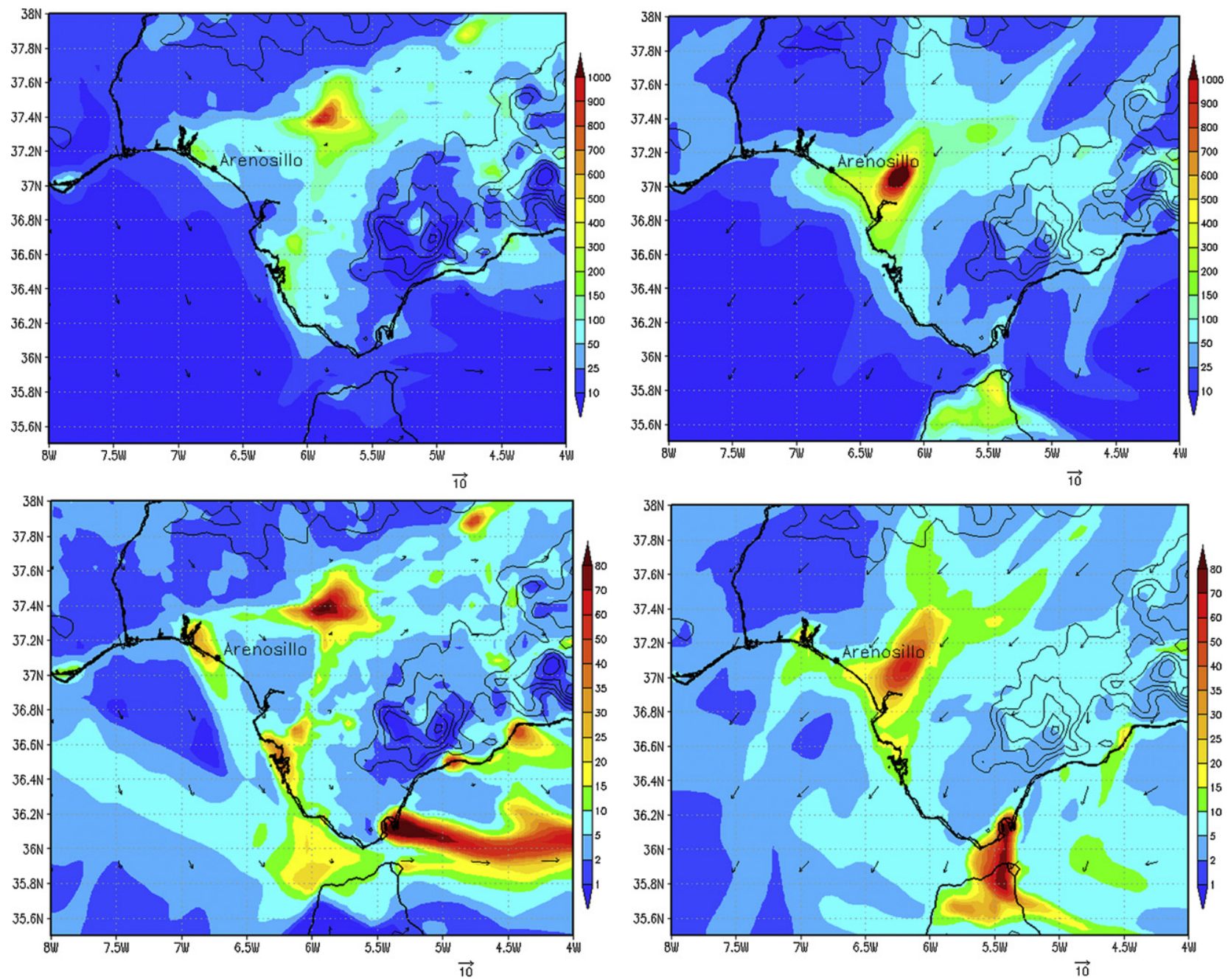

Fig. 4. HONO (ppt) -up- and $\mathrm{NO}_{2}\left(\mu \mathrm{g} \mathrm{m}^{-3}\right)$-down- concentrations as predicted for WRF-ARW/HERMES/CMAQ in the NO2H case at 6:00 UTC - 24/11/2008 (left), and 20:00 UTC 25/11/2008 (right).
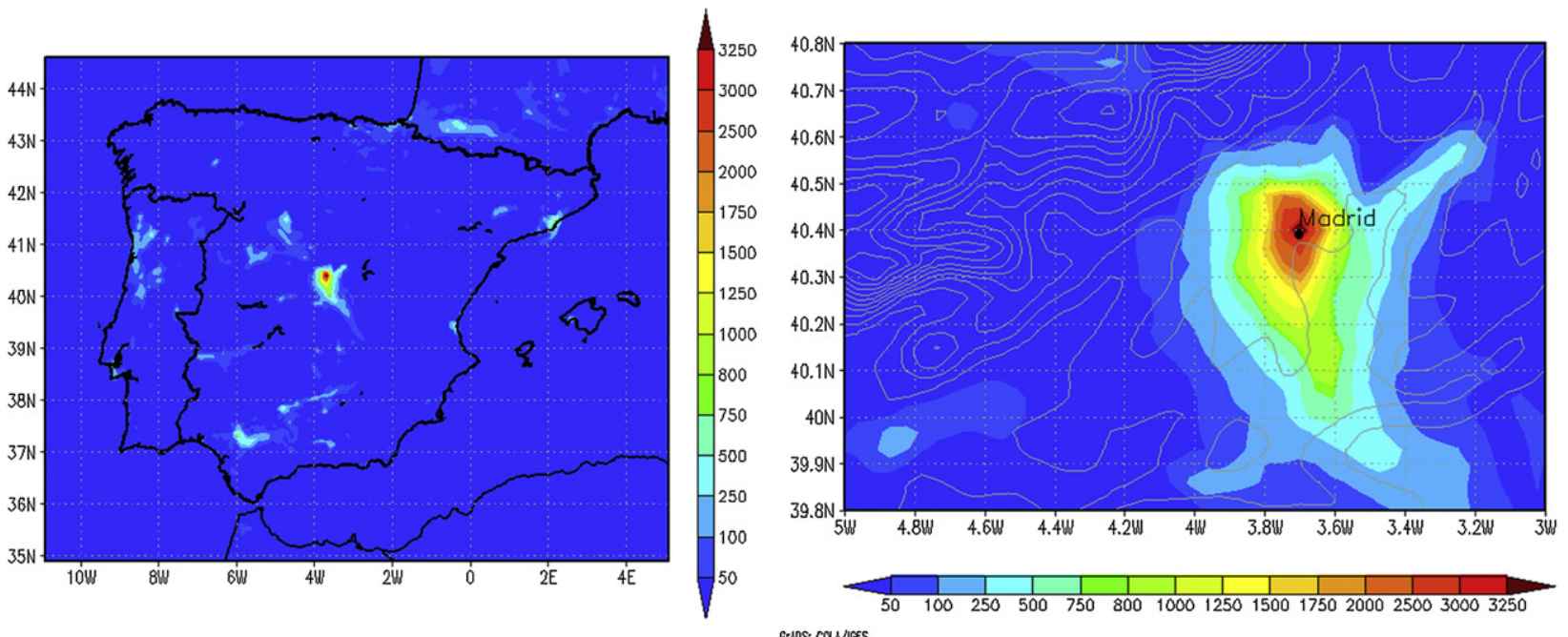

Fig. 5. HONO levels (ppt) in Spain at 9:00 UTC of November 25, 2008, as predicted by the WRF-ARW/HERMES/CMAQ model in the NO2H case (left) and zoom over the Madrid urban area (right). 
Peak HONO levels in Spain are found over densely populated urban areas (Fig. 5), up to 3400 ppt and 2000 ppt for the Madrid (9:00 UTC, November 25) and Barcelona urban areas (19:00 UTC, November 26), respectively. Trends follow the expected diurnal cycle, with a concentration build-up from 15:00 h UTC onward. HONO peaks either in late afternoon or early morning, depending on the area, and HONO midday concentrations are consistently below $100 \mathrm{ppt}$. Predicted values are in the range of observations in urban areas worldwide.

\subsection{HONO contribution to $\mathrm{OH}$ release, effects on secondary pollutants}

Photolysis of ozone $\left(\mathrm{O}_{3}\right)$ in the presence of water vapor is a major hydroxyl radical source in the lower troposphere (Atkinson, 2000). The IRR analysis (Gipson, 1999) is applied here to a reduced domain $(20 \times 20$ cells) defined over the Madrid urban area. The goal is to assess the importance of HONO as a source of OH compared to O1D reaction with water vapor. In this case, $\mathrm{HONO}$ is the dominant $\mathrm{OH}$ source in the early morning (Fig. 6). From 12:00 UTC onward, photolysis of $\mathrm{O}_{3}$ becomes the dominant source, as HONO concentration decays. These results are comparable to those calculated by Sörgel et al. (2011) from the DOMINO measurement campaign in El Arenosillo. There, they quantified the integrated contribution of HONO to $\mathrm{OH}$ release being $20 \%$ higher than the $\mathrm{O}^{1} \mathrm{D}$ reaction with water vapor. Our results confirm that HONO is not only important as an $\mathrm{OH}$ precursor in the early morning in rural areas, but also in urban environments. For the selected wintertime episode, the integrated contribution of $\mathrm{HONO}$ photolysis to $\mathrm{OH}$ formation is quantified to be $26 \%$ higher than $\mathrm{O}_{3}$ photolysis (taking the total production as a reference). Further analysis should be performed during summertime, when $\mathrm{O}_{3}$ concentrations are specially enhanced in Spain due to the meteorological conditions: high solar radiation indexes and frequent stagnant conditions, which favor the accumulation of secondary pollutants. However, since $\mathrm{O}_{3}$ maxima normally occur in downwind areas from the main $\mathrm{NO}_{x}$ sources, the HONO photolysis is presumed to be still an important $\mathrm{OH}$ source during summertime in urban areas, as has been proved already in previous studies worldwide (i.e. Alicke et al., 2002).

It is important to adequately reproduce $\mathrm{OH}$ cycles within air quality models due to its impact on both gaseous pollutants and aerosol levels. During the episode studied here, main air quality problems are centered in large urban areas (i.e. Madrid, Barcelona, Valencia and Bilbao) with high $\mathrm{NO}_{2}$ and $\mathrm{PM}_{2.5}$ levels. Maximum concentrations in Madrid are found during the morning traffic rush hour (9:00 UTC) for November 25, with $\mathrm{NO}_{2}$ levels up to $125 \mu \mathrm{g} \mathrm{m}^{-3}$ and $\mathrm{PM}_{2.5}$ up to $34 \mu \mathrm{g} \mathrm{m}^{-3}$. Wintertime meteorological conditions are usually associated to low $\mathrm{O}_{3}$ concentrations. The model slightly overpredicts background $\mathrm{O}_{3}$ levels for November 24-27, with an average predicted concentration of $81.9 \mu \mathrm{g} \mathrm{m}^{-3}$ (Table 2 ).

$\mathrm{NO}_{2}$ concentration near main $\mathrm{NO}_{x}$ emission sources is slightly higher in the BASE case than in those cases including HONO emissions. This is mainly attributed to the differential $\mathrm{NO}_{x}$ speciation in emissions, which characterizes $10 \%$ of $\mathrm{NO}_{x}$ from on-road traffic as $\mathrm{NO}_{2}$ in the BASE case and $9.2 \%$ in those cases including HONO emissions. This effect is reversed by HONO chemistry in large urban areas, namely Barcelona and Madrid, when HONO release is the highest. There, $\mathrm{NO}_{2}$ levels for the $\mathrm{NO} 2 \mathrm{H}$ case are slightly higher than in the BASE case during the morning (from 10:00 UTC to $14: 00$ UTC). This effect is attributed to the higher oxidation capacity of the atmosphere and it has been already reported for similar studies elsewhere (i.e. Li et al., 2010). However, those changes do not affect $\mathrm{NO}_{2}$ predicted peaks in Spanish urban areas.

The production of $\mathrm{OH}$ from HONO photolysis in urban areas in the early morning increases the oxidation capacity of the atmosphere, thus the high $\mathrm{NO}_{x}$ levels from traffic emissions are likely to further oxidize and yield nitric acid $\left(\mathrm{HNO}_{3}\right)$. Gas phase $\mathrm{HNO}_{3}$ can then partition into the aerosol phase, or be absorbed onto existing aerosols to form nitrate aerosols $\left(\mathrm{NO}_{3}^{-}\right)$. In the Madrid urban area, $\mathrm{PM}_{2.5}$ concentration increases up to $3.5 \mu \mathrm{g} \mathrm{m}^{-3}$ for November 25 at 10:00 UTC; BASE case $\mathrm{PM}_{2.5}$ concentration is $22.0 \mu \mathrm{g} \mathrm{m}^{-3}$ (Fig. 7). $62 \%$ of the $\mathrm{PM}_{2.5}$ change is attributed to enhanced nitrate formation. This is the case also in Barcelona for November 26 at 11:00 UTC, when $\mathrm{PM}_{2.5}$ concentration raises $2.1 \mu \mathrm{g} \mathrm{m}^{-3}$, from $20.0 \mu \mathrm{g} \mathrm{m}^{-3}$ predicted on the BASE case. Nitrate aerosols increase by $1.6 \mu \mathrm{g} \mathrm{m}^{-3}$ in this case. Ammonium aerosols and secondary organic aerosols (SOA) show also slight increases due to the introduction of HONO, but to a much lower extent than $\mathrm{NO}_{3}^{-}$. The effect on SOA should be assessed also during summertime, when biogenic volatile organic compound emissions are larger and therefore there is greater abundance of precursors.

The additional $\mathrm{OH}$ release in the early morning due to HONO ( $\mathrm{NO} 2 \mathrm{H}$ case) does not cause a significant impact on $\mathrm{O}_{3}$ levels. Background concentrations remain unaffected. Areas that are located downwind major HONO sources (i.e. downwind of urban areas), do not show significant variations either. Downtown $\mathrm{O}_{3}$ levels in Madrid are slightly affected during the morning, increasing

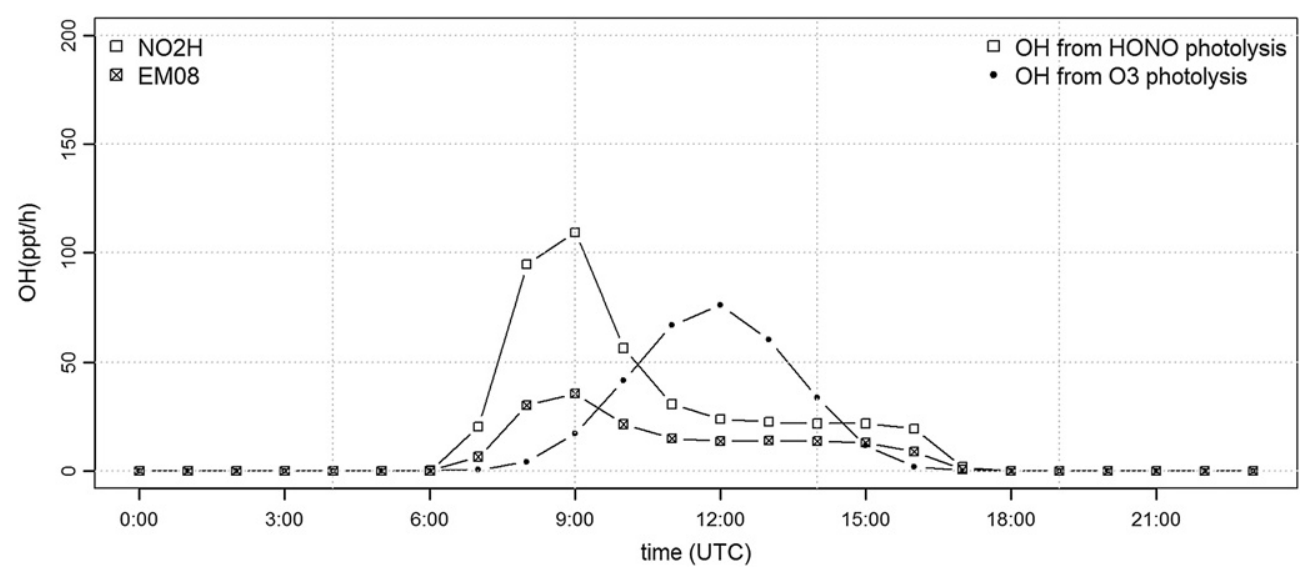

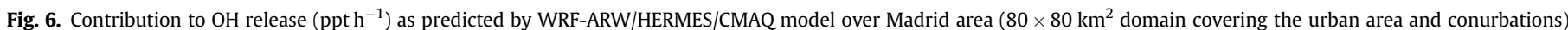

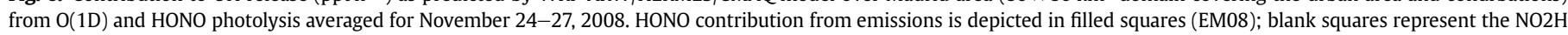
case including emissions and heterogeneous $\mathrm{NO}_{2}$ hydrolysis on surfaces. 

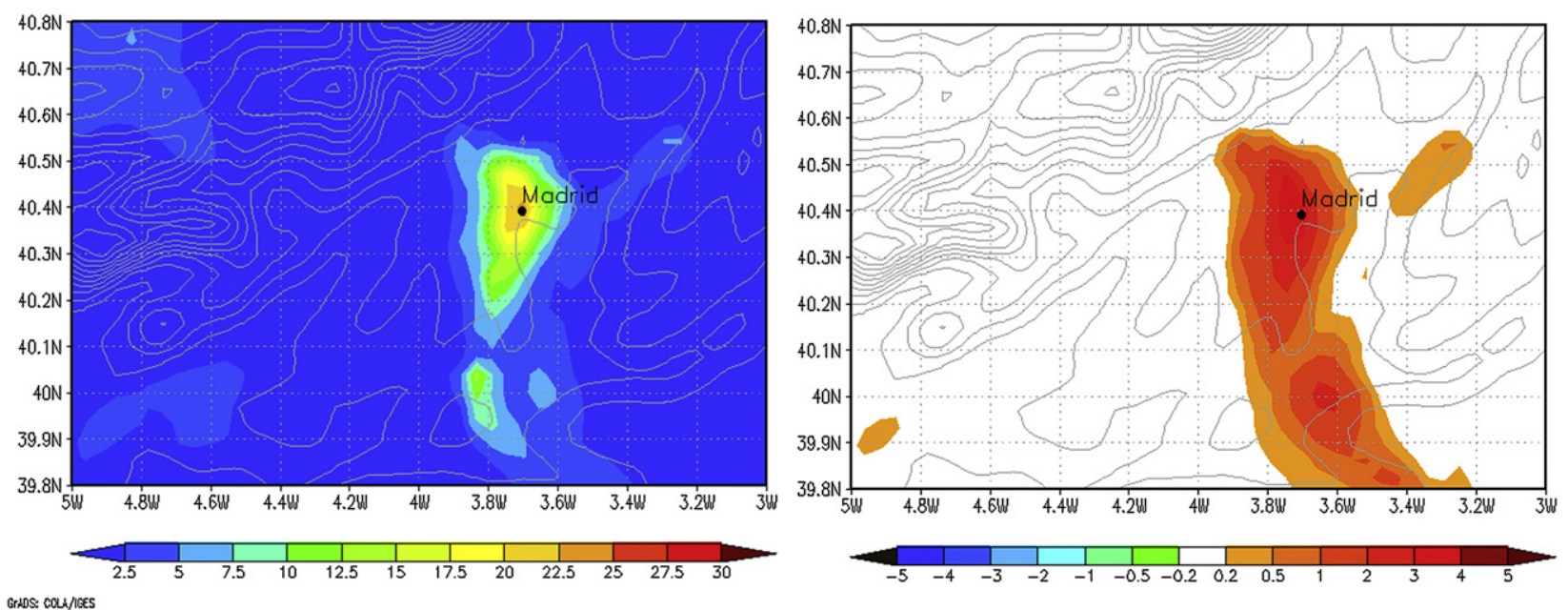

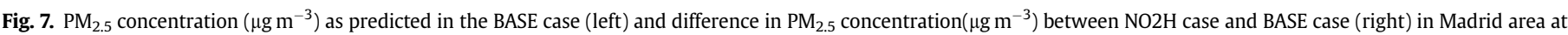
10:00 UTC of November 25, as predicted by WRF-ARW/HERMES/CMAQ model.

up to $4 \mu \mathrm{g} \mathrm{m}^{-3}$ (at $12: 00 \mathrm{UTC}$, November 25 ), equivalent to a $10 \%$ variation. Urban centers are usually characterized by low $\mathrm{O}_{3}$ concentrations, below $45 \mu \mathrm{g} \mathrm{m}^{-3}$ in the aforementioned situation, due to the fresh $\mathrm{NO}$ emissions from traffic that act as an $\mathrm{O}_{3}$ sink. Therefore, $\mathrm{O}_{3}$ peaks remain unaffected.

\section{Conclusions}

Direct emissions and $\mathrm{NO}_{2}$ hydrolysis on ground surfaces significantly improve the WRF-ARW/HERMES/CMAQ performance in predicting HONO levels in Spain. Modeled HONO levels follow the diurnal evolution and capture observed levels at the El Arenosillo station (correlation of 0.55; MNBE of -55.2\%). Discrepancies between the model and observations are larger when industrial plumes are affecting the area, suggesting that there are still missing HONO sources in the model, which could be attributed both to industrial derived emissions and additional chemical pathways not included in the model.

The available surface for reaction is a key factor for HONO production via heterogeneous chemistry. HONO production stands out in urban areas, considered as active surfaces in the model, and main $\mathrm{NO}_{2}$ focus in Spain. The effects of $\mathrm{NO}_{2}$ hydrolysis on aerosol surfaces are negligible. Detailed kinetics parameterizations including the dependence on relative humidity and solar radiation density do not produce significant changes on HONO levels, at least for moderately polluted urban areas such as those considered in the present work. Previous modeling studies and field campaigns presented evidence of photolytic HONO sources that are not reproduced by our model, thus results shown in this study should be considered as a lower limit for possible effects of HONO on air quality levels.

HONO is quantified for the selected wintertime episode as the main $\mathrm{OH}$ source in the early morning in urban areas, with its contribution $26 \%$ higher than that attributed to $\mathrm{O}_{3}$ photolysis in presence of water vapor. $\mathrm{OH}$ release affects particularly nitrate aerosol levels in urban areas, but also ammonium and secondary organic aerosols. Increases in $\mathrm{PM}_{2.5}$ predictions up to $14 \%$ are quantified. This effect is especially important in wintertime conditions as those studied here, when major air quality problems are related to $\mathrm{PM}_{2.5}$ levels in urban areas of Spain. $\mathrm{O}_{3}$ and $\mathrm{NO}_{2}$ show slight increases during morning in urban areas, however, maximum concentration predictions remain unaffected. The effects of HONO sources during photochemical pollution episodes, when $\mathrm{O}_{3}$ levels are also a major concern, should be explored.
Further research is needed to provide better characterization of available ground surfaces for reaction, kinetics parameterization of heterogeneous reactions and other possible diurnal HONO sources, within air quality models. In the meantime, at least $\mathrm{NO}_{2}$ hydrolysis on ground surfaces and direct traffic emissions should be included within modeling frameworks, as their impact on secondary pollutants is proven.

\section{Acknowledgements}

The authors gratefully acknowledge the collaboration with the group Atmospheric Integrated Research at University of California, Irvine, especially Barbara Finlayson-Pitts for the helpful discussions. Special thanks to M. Sörgel for providing HONO measurements from the DOMINO campaign, and M. T. Pay for help in the observation data treatment. This project is funded by the CALIOPE project of the Spanish Ministry of the Environment (441/2006/312.1, A357/2007/2-12.1,157/PC08/3-12.0)) and grants CGL200802818-CLI and CGL2010-19652 of the Spanish Ministry of Science and Innovation. All the simulations were performed on the Marenostrum Supercomputer of the Barcelona Supercomputing Center-Centro Nacional de Supercomputación (Barcelona, Spain).

\section{Appendix. Supplementary data}

Supplementary data associated with this article can be found, in the online version, at doi:10.1016/j.atmosenv.2012.02.079.

\section{References}

Alicke, B., Platt, U., Stutz, J., 2002. Impact of nitrous acid photolysis on the total hydroxyl radical budget during the Limitation of Oxidant Production/Pianura Padana Produzione di Ozono study in Milan. Journal of Geophysical Research 107 (D22), 8196-8205.

Alicke, B., Geyer, A., Hofzumahaus, A., Holland, F., Konrad, S., Patz, H.W., Schafer, J., Stutz, J., Volz-Thomas, A., Platt, U., 2003. OH formation by HONO photolysis during the BERLIOZ experiment. Journal of Geophysical Research 108 (D4), 8247-8264.

Ammann, M., Kalberer, M., Jost, D.T., Tobler, L., Rossler, E., Piguet, D., Gaggeler, H.W., Baltensperger, U., 1998. Heterogeneous production of nitrous acid on soot in polluted air masses. Nature 395 (6698), 157-160.

An, J., Li, Y., Wang, F., Xie, P., 2011. Impacts of photoexcited NO2 chemistry and heterogeneous reactions on concentrations of $\mathrm{O}_{3}$ and NOy in Beijing, Tianjin and Hebei Province of China. In: Mazzeo, Nicolas (Ed.), Air Quality-Models and Applications, ISBN 978-953-307-307-1.

Atkinson, R., 2000. Atmospheric chemistry of VOCs and NOx. Atmospheric Environment 34, 2063-2101 
Aumont, B., Chervier, F., Laval, S., 2003. Contribution of HONO sources to the NOx/ $\mathrm{HOx} / \mathrm{O}_{3}$ chemistry in the polluted boundary layer. Atmospheric Environment 37, 487-498.

Baldasano, J.M., Jiménez-Guerrero, P., Jorba, O., Pérez, C., López, E., Güereca, P., Martín, F., Vivanco, M.G., Palomino, I., Querol, X., Pandolfi, M., Sanz, M.J., Diéguez, J.J., 2008a. CALIOPE: an operational air quality forecasting system for the Iberian Peninsula, Balearic islands and Canary islands e first annual evaluation and ongoing developments. Advances in Science and Research 2, 89-98.

Baldasano, J.M., Güereca, L.P., López, E. Gassó, S., Jiménez-Guerrero, P., 2008b. Development of a high-resolution $(1 \mathrm{~km} \times 1 \mathrm{~km}, 1 \mathrm{~h})$ emission model for Spain: the High-Elective Resolution Modelling Emission System (HERMES). Atmospheric Environment 42, 7215-7233.

Baldasano, J.M., Pay, M.T., Jorba, O., Gassó, S., Jiménez-Guerrero, P., 2011. An annual assessment of air quality with the CALIOPE modeling system over Spain. Science of the Total Environment 409 (11), 2163-2178.

Bejan, Y., Abd el Aal, I., Barnes, I., Benter, T., Bohn, B., Wiesen, P., Kleffmann, J., 2006. The photolysis of ortho-nitrophenols: a new gas-phase source of HONO. Physical Chemistry Chemical Physics 8, 2028-2035.

Binkowski, F.S., Roselle, S.J., 2003. Models-3 Community Multiscale Air Quality (CMAQ) model aerosol component. 1. Model description. Journal of Geophysical Research 108 (D6), 4183-4194.

Byun, D., Schere, K.L., 2006. Review of the governing equations, computational algorithms, and other components of the Models-3 Community Multiscale Air Quality (CMAQ) modeling system. Applied Mechanics Reviews 59 (2), 51-77.

Calvert, J.G., Yarwood, G., Dunker, A.M., 1994. An evaluation of the mechanism of nitrous acid formation in the urban atmosphere. Research on Chemical Intermediates 20, 463-502.

Carlton, A., Bhave, P.V., Napelenok, S.L., Edney, E.O., Sarwar, G., Pinder, R.G., Pouliot, G.A., Houyoux, M., 2010. Model representation of secondary organic aerosol in CMAQv4.7. Environmental Science and Technology 44, 8553-8560.

Carr, S., Heard, D.E., Blitz, M.A., 2009. Comment on "Atmospheric Hidroxyl Radical Production from Electronically Excited $\mathrm{NO}_{2}$ and $\mathrm{H}_{2} \mathrm{O}$ ". Science 324 (5925), 336b.

DGT, 2010. Dirección General de Tráfico. Estadísticas e Indicadores. Available at: http://www.dgt.es/portal/es/seguridad_vial/estadistica/parque_vehiculos/ series_historicas_parque/.

Elshorbany, Y.F., Kurtenbach, R., Wiesen, P., Lissi, E., Rubio, M., Villena, G., Gramsch, E., Rickard, A.R., Pilling, M.J., Kleffmann, J., 2009. Oxidation capacity of the city air of Santiago, Chile. Atmospheric Chemistry and Physics 9, 2257-2273.

Finlayson-Pitts, B.J., Wingen, L.M., Sumner, A.L., Syomin, D., Ramazan, K.A., 2003. The heterogeneous hydrolysis of $\mathrm{NO}_{2}$ in laboratory systems and in outdoor and indoor atmospheres: An integrated mechanism. Physical Chemistry Chemical Physics 5, 223-242.

Foley, K.M., Roselle, S.J., Appel, K.W., Bhave, P.V., Pleim, J.E., Otte, T.L., Mathur, R., Sarwar, G., Young, J.O., Gilliam, R.C., Nolte, C.G., Kelly, J.T., Gilliland, A.B., Bash, J.O., 2010. Incremental testing of the community multiscale air quality (CMAQ) modelling system version 4.7. Geoscience Model Development 3, 205-226.

Gipson, L.G. 1999. Science Algorithms of the EPA Models-3 Community Multiscale Air Quality (CMAQ) Modeling System: Process Analysis, EPA/600/R-99/030. US Environmental Protection Agency alone (Chapter 16), Research Triangle Park, North Carolina. Available on line at: http://www.epa.gov/AMD/CMAQ/CMAQscienceDoc. html.

INERIS, 2009. Documentation of the Chemical Transport Model CHIMERE (vs. 2008). Copyright $(2007$ Institut Pierre-Simon Laplace, INERIS, LISA (C.N.R.S.).

Kirschtetter, T.W., Harley, R.A., Littlejohn, D., 1996. Measurement of nitrous acid in motor vehicle exhaust. Environmental Science and Technology 30, 2843-2849.

Kleffmann, J., Becker, K.H., Wiesen, P., 1998. Heterogeneous $\mathrm{NO}_{2}$ conversion processes on acid surfaces: possible atmospheric implications. Atmospheric Environment 32, 2721-2729.

Kleffmann, J., Benter, T., Wiesen, P., 2004. Heterogeneous reaction of nitric acid with nitric oxide on glass surfaces under simulated atmospheric conditions. The Journal of Physical Chemistry A 108, 5793-5799.

Kleffmann, J., Wiesen, P., 2005. Heterogeneous conversion of $\mathrm{NO}_{2}$ and $\mathrm{NO}$ on $\mathrm{HNO}_{3}$ treated soot surfaces: atmospheric implications. Atmospheric Chemistry and Physics 5, 77-83.

Kurtenbach, R., Becker, K.H., Gomes, J.A.G., Kleffmann, J., Lorzer, J.C., Spittler, M., Wiesen, P., Ackermann, R., Geyer, A., Platt, U., 2001. Investigations of emissions and heterogeneous formation of HONO in a road traffic tunnel. Atmospheric Environment 35, 3385-3394.

Li, S., Matthews, J., Sinha, A., 2008. Atmospheric hydroxyl radical production from electronically excited $\mathrm{NO}_{2}$ and $\mathrm{H}_{2} \mathrm{O}$. Science 319, 1657-1660.

Li, S., Matthews, J., Sinha, A., 2009. Response to comment on atmospheric hydroxyl radical production from electronically excited $\mathrm{NO}_{2}$ and $\mathrm{H}_{2} \mathrm{O}$. Science 324, 336c.

Li, G., Lei, W., Zavala, M., Volkamer, R., Dusanter, S., Stevens, P., Molina, L.T., 2010. Impacts of HONO sources on the photochemistry in Mexico City during the MCMA-2006/MILAGO Campaign. Atmospheric Chemistry and Physics 10, 6551-6567.
Li, Y., An, Y., Min, M., Zhang, W., Wang, F., Xie, P., 2011. Impacts of HONO sources on the air quality in Beijing, Tianjin and Hebei Province of China. Atmospheric Environment 45 (27), 4735-4744.

Michalakes, J., Dudhia, J., Gill, D., Henderson, T., Klemp, J., Skamarock, W., Wang, W. 2004. The Weather research and forecast model: software architecture and performance. In: Mozdzynski, E.G. (Ed.), Proceedings of the Eleventh ECMWF Workshop on the Use of High Performance Computing in Meteorology, 25-29 October 2004, Reading, UK, pp. 117-124.

Monge, M.E., D’Anna, B., Mazri, L., Giroir-Fendler, A., Ammann, M., Donaldson, D.J., George, C., 2010. Light changes the atmospheric reactivity of soot. Proceedings of the National Academy of Sciences of the United States of America 107 (15) 6605-6609.

Pay, M.T., Jiménez-Guerrero, P., Jorba, O., Basart, S., Pandolfi, M., Querol, X Baldasano, J.M., 2012. Spatio-temporal variability of concentrations and speciation of particulate matter across Spain in the CALIOPE modeling system. Atmospheric Environment 46, 376-396.

Pay, M.T., Piot, M., Jorba, O., Gassó, S., Gonçalves, M., Basart, S., Dabdub, D., JiménezGuerrero, P., Baldasano, J.M., 2010. A full year evaluation of the CALIOPE-EU air quality modelling system over Europe for 2004. Atmospheric Environment 44, 3322-3342.

Platt, U., Perner, D., Harris, G.W., Winer, A.M., Pitts, J.N., 1980. Observations of nitrous acid in an urban atmosphere by differential optical absorption. Nature 285 312-314.

Ren, X., Harder, H., Martinez, M., Lesher, R.L., Oliger, A., Shirley, T., Adams, J. Simpas, J.B., Brune, W.H., 2003. HOx concentrations and $\mathrm{OH}$ reactivity observations during the PMTACS-NY 2001 campaign in New York City. Atmospheric Environment 37, 3627-3637.

Rivera-Figueroa, A.M., Sumner, A.L., Finlayson-Pitts, B.J., 2003. Laboratory studies of potential mechanisms of renoxification of tropospheric nitric acid. Environmental Science and Technology 37, 548-554.

Rohrer, F., Bohn, B., Brauers, T., Brüning, D., Johnen, F.J., Wahner, A., Kleffmann, J., 2005. Characterization of the photolytic HONO-source in the atmosphere simulation chamber SAPHIR. Atmospheric Chemistry and Physics 5 , 2189-2201.

Sarwar, S., Roselle, S., Mathun, R., Appel, W., Dennis, R.L., Vogel, B., 2008. A comparison of CMAQ HONO predictions with observations from the Northeast Oxidant and Particle Study. Atmospheric Environment 42, 5760-5770.

Skamarock, W.C., Klemp, J.B., 2008. A time-split nonhydrostatic atmospheric model for weather research and forecasting applications. Journal of Computational Physics 227 (7), 3465-3485.

Sörgel, M., Regelin, E., Bozem, H., Diesch, J.M., Drewnick, F., Fischer, H., Harder, H. Held, A., Hosaynali-Beygi, Z., Martinez, M., Zetzsch, C., 2011. Quantification of the unknown HONO daytime source and its relation to NO2. Atmospheric Chemistry and Physics 11, 10433-10447.

Stemmler, K., Ammann, M., Donders, C., Kleffmann, J., George, C., 2006. Photosensitized reduction of nitrogen dioxide on humic acid as a source of nitrous acid. Nature 440, 195-198.

Stemmler, K., Ndour, M., Elshorbany, Y., Kleffmann, J., D’Anna, B., George, C., Bohn, B. Ammann, M., 2007. Light induced conversion of nitrogen dioxide into nitrous acid on submicron humic acid aerosol. Atmospheric Chemistry and Physics 7 $4237-4248$

Stutz, J., Alicke, B., Ackermann, R., Geyer, A., Wang, S., White, A.B., Williams, E.J., Spicer, C.W., Fast, J.D., 2004. Relative humidity dependence of HONO chemistry in urban areas. Journal of Geophysical Research 109, D03307.

Su, H., Cheng, Y., Oswald, R., Behrendt, T., Trebs, I., Meixner, F.X., Andreae, M.O Cheng, P., Zhang, Y., Pöschl, U., 2011. Soil nitrite as a source of atmospheric HONO and $\mathrm{OH}$ radicals. Science 333, 1616-1618.

Vogel, B., Vogel, H., Kleffmann, J., Kurtenbach, R., 2003. Measured and simulated vertical profiles of nitrous acid. Part II. Model simulations and indications for a photolytic source. Atmospheric Environment 37, 2957-2966.

Wennberg, P.O., Dabdub, D., 2008. Rethinking ozone production. Science 319 1624-1625

Wentzell, J.J.B., Schiller, C.L., Harris, G.W., 2010. Measurements of HONO during BAQS-Met. Atmospheric Chemistry and Physics 10, 12285-12293.

Winer, A.M., Biermann, H.W., 1994. Long pathlength differential optical absorption spectroscopy (DOAS) measurements of gaseous $\mathrm{HONO}, \mathrm{NO}_{2}$ and $\mathrm{HCHO}$ in the California South Coast Air Basin. Research on Chemical Intermediates 20, 423-445.

Yarwood, G., Rao, S., Yocke, M., Whitten, G.Z., 2005. Updates to the carbon bond chemical mechanism: CB05, Final report n RT-04-00675, US-EPA. December, 8, 2005.

Zhou, X., Gao, H., He, Y., Huang, G., Bertman, S.B., Civerolo, K., Schwab, J., 2003. Nitric acid photolysis on surfaces in low-NOx environments: significant atmospheric implications. Geophysical Research Letters 30 (23), 2217.

Ziemba, L.D., Dibb, J.E., Griffin, R.J., Anderson, C.H., Whitlow, S.I., Lefer, B.L. Rappenglu, B., Flynn, J., 2010. Heterogeneous conversion of nitric acid to nitrous acid on the surface of primary organic aerosol in an urban atmosphere. Atmospheric Environment 44, 4081-4089. 